\title{
Detection of Citrus Bent Leaf Viroid in Citrus Orchards of Sargodha, Pakistan
}

\author{
Faheema Bakhtawar, Yasir Iftikhar, Muhammad Ahmed Zeshan and Muhammad Imran Hamid \\ Department of Plant Pathology, College of Agriculture, University of Sargodha, \\ Sargodha, Pakistan, 40100, Email: yasir.iftikhar@uos.edu.pk
}

\begin{abstract}
Bakhtawar, F., Y. Iftikhar, M. A. Zeshan and M. I. Hamid. 2021. Detection of Citrus Bent Leaf Viroid in Citrus Orchards of Sargodha, Pakistan. Arab Journal of Plant Protection, 39(2): 159-163.

A study was conducted to monitor the Citrus bent leaf viroid (CBLVd) in citrus growing areas of district Sargodha, Pakistan during 2017-2018. Collected samples were tested by RT-PCR using specific primers. PCR positive samples were used to confirm the CBLVd incidence and severity on different citrus varieties grown at different regions of Sargodha. Maximum disease incidence was recorded in Kot Momin with the mean value of $24 \%$, with severe symptoms of bark cracking, backward leaf bent and stunting. Minimum disease incidence was recorded in in Sillanwali region with the mean value of 3.33\%. The symptoms in Sillanwali were only yellowing and slight leaf bent. Maximum severity was observed in Kot momin $(0.60 \%)$. Molecular detection of CBLVd by RT-PCR confirmed the diagnosis of the viroid. This survey was carried out for the first time in Sargodha district to monitor the occurrence of citrus bent leaf viroid following the first report of its detection in Pakistan in 2009. Since many declining citrus trees were found negative to CBLVd testing, other causal agents can be involved, and extensive surveys are still required in the near future.

Keywords: Citrus, RT-PCR, CBLVd, Disease incidence, viroid, Sargodha, Pakistan
\end{abstract}

\section{Introduction}

Citrus plays a virtal role in human diet because of nutritional value. It is rich source of minerals and vitamin, especially vitamin C. In Pakistan, citrus represent $34 \%$ of the total fruit production in the country. Pakistan at present is ranked 16 in citrus production worldwide. There are number of biotic and abiotic factors that affect citrus fruits quality and yield. Many biotic factors such as fungi, bacteria, nematodes, viruses, viroids and phytoplasmas can cause diseases in citrus. Viroids are known as the smallest, low molecular weight circular naked single stranded RNA pathogens. Different economically important viroids were found to infect different crop plants such as coconut cadang cadang viroid (CCCVd), Potato spindle tuber viroid and Chrysanthemum stunt viroid (Hadidi et al., 2003). There are seven viroids and their variants that have been reported to infect citrus: Citrus bent leaf viroid (CBLVd), Citrus exocortis viroid (CEVd), citrus dwarfing viroid (CDVd), Hop stunt viroid (HSVd), Citrus bark cracking viroid $(\mathrm{CBCVd})$ and Citrus viroid original source (CVd-OS) (Serra et al., 2008; Duran-Vila et al., 2000; Ito et al., 2002). Mechanical inoculation and vegetative propagation (grafting, budding) are the means of viroids spread from infected to healthy plants (Garnsey et al., 2002; Ito et al., 2002). Common symptoms produced under field conditions in response to citrus infection with viroids are mainly stunting, bark cracking, backward leaf bent, yellowing of leaves, leaf pinholes, low yield which all contribute towards tree decline (Eiras et al., 2013). CBLVd has been reported in different parts of the world to affect citrus production in Asia (Al-Shariqi et al., 2013; Mazhar et al., 2014). This viroid has different variants which includes CVd-Ia, CVd-Ib and CVd-1-LSS (Ito et al., 2002). CVd-Ib composed of 315-319 nt, was first sequenced and renamed as CBLVd, whereas CVd-Ia is composed of 327-329 nt. The CVd-I-LSS (325-330nt) isolates have only $82-85 \%$ sequence similarity with CVd-I variants. CBLVd has also been reported in Pakistan (Cao et al., 2009). Field surveys showed that CBLVd is not associated with visible symptoms such as reduced canopy size and fruit, leaf bending, leaf rolling commonly observed on infected plants (Semancik et al., 1997; Hutton et al., 2000). Although, citrus viroids have been reported earlier in Pakistan (Catara et al., 1988; Cao et al., 2009), but rare or no information is available regarding incidence and role of citrus viroids in citrus decline. Because of their mention in the literature, CEVd and CBLVd were tested for in the different samples collected, but only CBLVd was detected. Accordingly, this study was initiated to investigate the occurrence of CBLVd in the Punjab, Pakistan.

\section{Material and Methods}

\section{Collection of Samples}

A survey was conducted in the different citrus orchards of Sargodha district during 2017-2018, which included Sargodha, Kot Momin, Bhalwal, Sahiwal, Shahpur, Bhera and Sillanwali areas. Samples were collected from the orchards with symptoms suggestive of viroids infection such as yellowing, backward leaf curling, bark cracking, pin holing, dwarfing and stunting (Table 1). In Sargodha district, the commonly grown citrus varieties Kinnow, Feutrell's early, Mosambi, and Lemonwere were surveyed, and a total of 150 samples/area was collected (Table 1). Trees, from which samples were collected, were marked for future investigation. Random leaf samples from symptomatic trees were collected in zipper bags and marked with all necessary

https://doi.org/10.22268/AJPP-039.2.159163

(C) 2021 Arab Society for Plant Protection الجمعية العربية لوقاية النبات 
information. Samples were brought into laboratory in an ice box and stored at $20{ }^{\circ} \mathrm{C}$ for further molecular detection.

\section{Disease Incidence}

Disease incidence was calculated by using the following formula based on molecular confirmation

$$
\operatorname{DI}(\%)=\frac{\text { No. of symptomatic trees }}{\text { Total No. of trees }} \times 100
$$

\section{Disease Severity}

A disease rating based on 0-4 scale was developed for CBLVd for a single tree, based on symptoms observed and confirmed by PCR. The disease severity rating scale was developed as a modification of a scale developed earlier for citrus greening disease (Akhtar and Ahmed 1999) in the light of symptomology, which is as follows: $0=$ Plant showing no yellowing (Asymptomatic); 1=1-10\% of plants showing yellowing and backward leaf bent; $2=11-25 \%$ of plants showing yellowing and backward leaf bent; $3=26-50 \%$ of plants showing yellowing and backward leaf bent along with bark cracking; $4=>50 \%$ of plants showing yellowing, backward leaf bent, bark cracking and stunting of plant.

\section{Nucleic Acid Extraction}

Nucleic acid extraction from the leaf samples was performed as reported earlier (Ito et al., 2002) with slight modifications as follows: $3 \mathrm{~g}$ of leaves were ground in liquid nitrogen using pestle and mortar. Ten $\mathrm{ml}$ of TESLP [0.13M Tris- $\mathrm{HCl}(\mathrm{pH}$ 8.9), 0.017 M EDTA (pH 7.0), $1 \mathrm{M} \mathrm{LiCl,} \mathrm{0.83 \%} \mathrm{SDS,} \mathrm{5 \%}$ PVP] buffer was added and the slurry was transferred to a 50 ml screw cap tube. $16 \mu l$ of 2-mercaptoethanol was then added into the mixture. Tubes were placed in a rotary shaker for thirty minutes at room temperature. After centrifugation at 11,000 rpm for 15 minutes, the supernatant was transferred to a new $50 \mathrm{ml}$ tube, and mixed with phenol:chloroform:isoamyl alcohol (PCA)(25:24:1) @ 3:2 ratio, thoroughly shaken by a vortex mixer and again centrifuged for phase separation, and the supernatant was poured into a new tube. A CA mixture (24:1) was added to the supernatant @ 4:3 ratios, and the tubes were centrifuged again under the same conditions. One volume of the supernatant obtained was added to 0.9 volume of $90 \%$ isopropanol. Tubes were inverted properly 3-4 times, to mix the contents well, and then incubated at $-20^{\circ} \mathrm{C}$ for $3-4 \mathrm{hrs}$ or overnight at $4^{\circ} \mathrm{C}$. Following centrifugation, the nucleic acid pellet was kept and the isopropanol supernatant was discarded. The pellet in $1.5 \mathrm{ml}$ micro centrifuge tube was washed with $1 \mathrm{ml}$ of $70 \%$ ethanol until a clean transparent pellet was obtained. The nucleic acid pellet was dissolved in 50 ul sterile double distilled water and stored at $-20^{\circ} \mathrm{C}$ until use.

Reverse transcription polymerase chain reaction was used to detect citrus bent leaf viroid using specific primers pair to produce an amplicon of 233bp; a reverse primer (-) 5'-TCGACGACGACCAGTCAGCT-3' and a forward Primer (+) 5'-TCCCCTTCACCCGAGCGCTGC$\left.3^{\prime}\right)$. Reverse transcription was carried out in two steps as reported earlier (Ito et al., 2002). The amplified PCR products were separated by using $2 \%$ agarose gel (Bernard and Duran-Vila, 2006). The gel was stained with ethidium bromide for 10 minutes and washed with distilled water for 5 minutes. Gel was visualized under UV light for bands appearance.

Table 1. Surveyed locations in Sargodha, Pakistan, from which symptomatic citrus samples were collected.

\begin{tabular}{|c|c|c|c|c|c|}
\hline $\begin{array}{l}\text { Location } \\
\text { (area) }\end{array}$ & $\begin{array}{c}\text { No. of } \\
\text { orchards }\end{array}$ & Age (Year) & $\begin{array}{c}\text { Total number } \\
\text { of samples } \\
\text { collected }\end{array}$ & $\begin{array}{c}\text { Number of positive } \\
\text { samples confirmed } \\
\text { by PCR } \\
\end{array}$ & $\begin{array}{l}\text { Symptoms } \\
\text { observed }\end{array}$ \\
\hline Sargodha & 5 & $5-20$ & 150 & 27 & $\begin{array}{l}\text { Yellowing of } \\
\text { leaves, Backward leaf } \\
\text { curling, Bark cracking, dwarfing }\end{array}$ \\
\hline Kot Momin & 5 & $7-25$ & 150 & 37 & $\begin{array}{l}\text { Yellowing, Backward leaf } \\
\text { curling, Bark cracking, pin } \\
\text { holing, stunting, dwarfing }\end{array}$ \\
\hline Bhalwal & 5 & $5-20$ & 150 & 20 & $\begin{array}{l}\text { Yellowing, Backward leaf } \\
\text { curling, dwarfing }\end{array}$ \\
\hline Sahiwal & 5 & $5-25$ & 150 & 15 & $\begin{array}{l}\text { Yellowing, Backward curling } \\
\text { of leaves, Bark cracking }\end{array}$ \\
\hline Shahpur & 5 & $5-20$ & 150 & 11 & $\begin{array}{l}\text { yellowing, Backward curling } \\
\text { of leaves }\end{array}$ \\
\hline Bhera & 5 & $5-20$ & 150 & 9 & $\begin{array}{l}\text { yellowing, backward curling } \\
\text { of leaves }\end{array}$ \\
\hline Sillanwali & 5 & $5-20$ & 150 & 5 & Yellowing \\
\hline
\end{tabular}




\section{Results and Discussion}

\section{Molecular detection of CBLVd}

Samples were tested through RT-PCR which confirmed the presence of CBLVd in all the areas of Sargodha district. Different citrus varieties were found to be infected with CBLVd. Expected amplicons of $\sim 233 \mathrm{bp}$ were obtained on the gel (Figure 1), and confirmed as positive samples of CBLVd by sequencing.

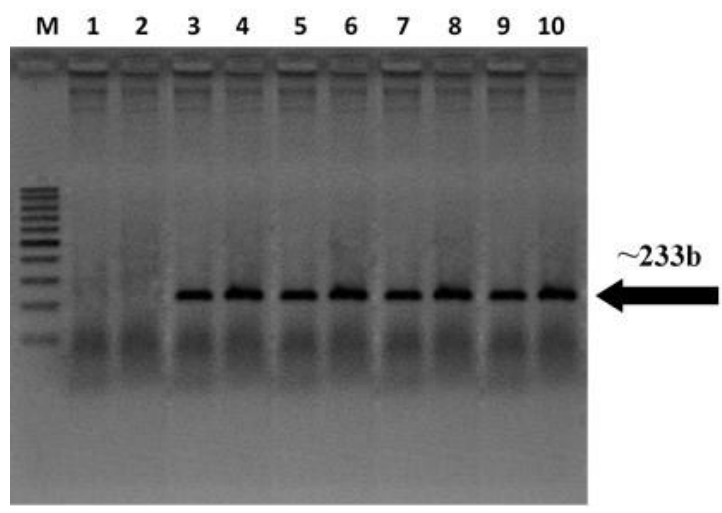

Figure 1. Detection of CBLVd in citrus tissue using RTPCR. Lane M= Molecular weight markers ladder; Lane1= Empty Lane 2= Negative control (only water); Lane 3-9= Infected citrus samples from different areas of Sargodha; Lane $10=$ Positive control.

\section{Disease incidence and severity in different areas}

Disease incidence and severity of CBLVd on the basis of symptoms followed by PCR confirmation was monitored in the citrus orchards of Sargodha district. There was a significant difference in disease incidence in different areas. Maximum disease incidence was found in Kot Momin (24.67\%) followed by Sargodha (18.67\%), whereas lowest disease incidence was in Sillanwali with the mean value of $3 \%$ (Figure 2).

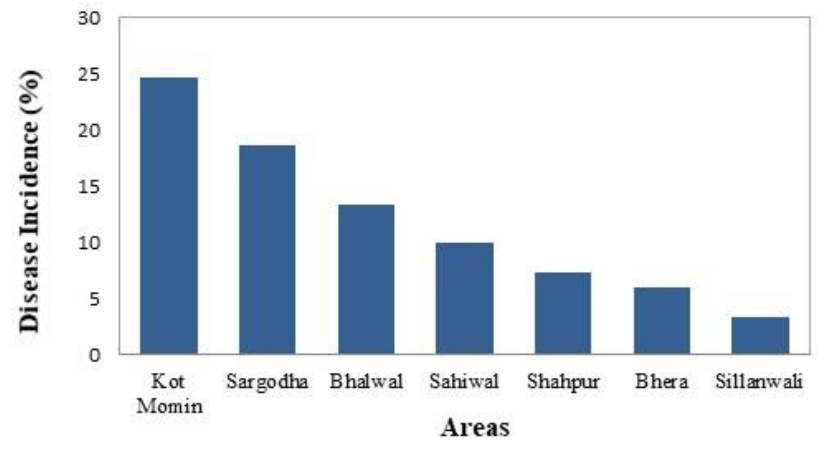

Figure 2. Disease incidence of CBLVd in all areas of Sargodha district.

Similarly, disease severity was also recorded and a similar trend as disease incidence was observed. Disease severity was significantly different among the different areas of district Sargodha. Maximum disease severity with the mean value of 0.60 was found in Kotmomin followed by
Sargodha (0.18). Least disease severity was found in Sillanwali with the mean value of 0.02 (Figure 3 ).

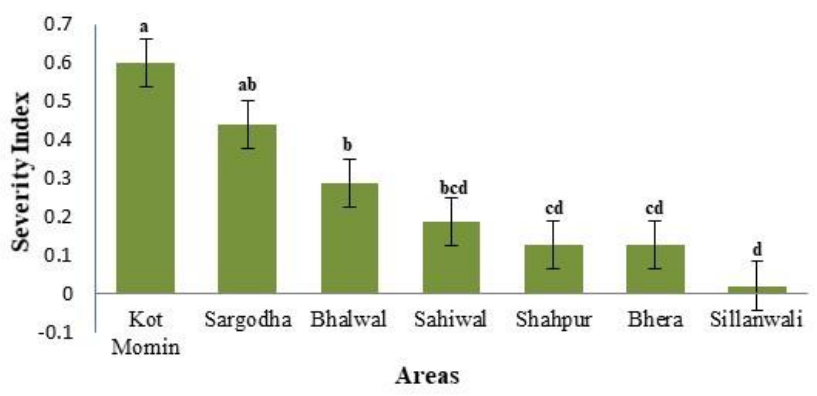

Figure 3. Disease Severity of CBLVd in all areas of Sargodha district.

The present study revealed that all citrus growing areas of the district Sargodha showed varied degree of infection with Citrus bent leaf viroid (CBLVd). CBLVd was detected and confirmed in this study. The conducted survey revealed that that maximum incidence was recorded in Kot Momin area followed by Sargodha area. Kinnow was the most cultivated variety in these areas and hence more infection of CBLVD was found, whereas, stunting and backward leaf bent were most common in declined citrus orchards. In Pakistan, the work on citrus viroid is limited to the first report of different citrus viroids in citrus orchards of Sargodha (Catara et al., 1988; Cao et al., 2009). The results of this study revealed that citrus at many locations was infected with CBLVd. The results of present study were in agreement with a previous study which reported that citrus orchards in Sargodha were infected with CBLVd and citrus tristeza virus (Catara et al., 1988; Cao et al., 2009). The molecular detection of CBLVd in this study was based on previous findings (Tangkanchanapas et al., 2018). Detection of CBLVd from Iran also suggested that isolates were introduced to Iran from Pakistan (Bagherian, 2016). Simultaneous detection of different citrus viroids have also been reported by Ito et al. (2002). A variant of CBLVd, CVd1-LSS, was also reported in Pakistan and it was concluded that there is a possible origin of CBLVd from Pakistan. The different isolates of CBLVd were found in all clades in the phylogenetic analysis (Wu et al., 2014). Therefore, detection of CBLVd in this study revealed that a comprehensive survey to monitor the other citrus viroids and viruses is urgently needed in major citrus growing areas of Pakistan, and establishing and standardization of detection techniques and survey protocols is instrumental in speeding up this process.

\section{Acknowledgement}

Authors are highly thankful to Higher Education Commission of Pakistan for funding this part of study under a project No. 6695, entitled, "Detection and characterization of citrus viroids in citrus growing areas of the Punjab, Pakistan". This study is also a part of $\mathrm{Ph}$. D. thesis research of the Faheema Bakhtawar in the Department of Plant Pathology, College of Agriculture, University of Sargodha. 


\section{References}

Akhtar, M.A. and I. Ahmad. 1999. Incidence of citrus greening disease in Pakistan. Pakistan Journal of Phytopathology, 11: 1-5.

Al-Shariqi, R.M., M.S. Al-Hammadi and A.M. Al-Sadi. 2013. First report of Citrus bent leaf viroid in the United Arab Emirates. Journal of Plant Pathology, 95(4): S4.71. https://doi.org/10.4454/JPP.V95I4.009

Bagherian, S.A.A. 2016. Citrus bent leaf viroid from Fars Province of Iran. Iranian Journal of Virology, 10(1): 17. https://doi.org/10.21859/isv.10.1.1

Bernard, L. and N. Duran-Vila. 2006. A novel RT-PCR approach for detection and characterization of citrus viroids. Molecular and Cellular Probes, 20: 105-113. https://doi.org/10.1016/j.mcp.2005.11.001

Cao, M.J., S. Atta, Y.Q. Liu., X.F. Wang, C.Y. Zhou, A. Mustafa and Y. Iftikhar. 2009. First Report of citrus bent leaf viroid and citrus dwarfing viroid from citrus in Punjab, Pakistan. Plant Disease, 93(8): 840. https://doi.org/10.1094/PDIS-93-8-0840C

Catara, A., A. Azzaro, S.M. Moghal and D.A. Khan. 1988. Virus, viroid and prokaryotic diseases of citrus in Pakistan. Pages 957-962. In: Proceedings of $6^{\text {th }}$ International Citrus Congress. R. Goren and K. Mendel. Balaban Publishers, Philadelphia.

Duran-Vila, N., J.S. Semancik and P. Broadbent. 2000. Viroid diseases, cachexia, and exocortis. Pages 51-54. In: Compendium of Citrus Diseases, second edition. L.W. Timmer, S.M. Garnsey and J.H. Graham (eds.). The American Phytopathological Society. USA.

Eiras, M., S.R. Silva, E.S. Stuchi, S.A. Carvalho and R.M. Garcez. 2013. Identification and characterization of viroids in 'Naveline ISA 315' sweet orange. Tropical Plant Pathology, 38: 58-62. https://doi.org/10.1590/S1982-56762013000100009
Garnsey, S.M., D.L. Zies, M. Irey, J.S. Sieburth, J.S. Semancik, L. Levy and M.E. Hilf. 2002. Practical field detection of citrus viroids in Florida by RT-PCR. Fifteenth IOCV Conference. https://escholarship.org/uc/item/9x08w06f

Hadidi, A., R. Flores, J.W. Randles and J.S. Semancik 2003. Viroids. Science Publisher, Inc.

Hutton, RJ., P. Broadbent and K.B. Bevington. 2000. Viroid dwarfing for high density plantings. Horticultural Reviews, 24: 277-317.

Ito, T., H. Ieki and K. Ozaki. 2002. Simultaneous detection of six citrus viroids and Apple stem grooving virus from citrus plants by multiplex reverse transcription polymerase chain reaction. Journal of Virological Methods, 106: 235-239. https://doi.org/10.1016/S0166-0934(02)00147-7

Mazhar, M.A., S.A.A. Bagherian, A.S. Ardakani and K. Izadpanah. 2014. Nucleotide Sequence and Structural Features of Hop Stunt Viroid and Citrus Bent Leaf Viroid Variants from Blighted Citrus Plants in Kohgiluyeh-Boyerahmad Province of Iran. Journal of Agriculture Sciences, 16: 657-665.

http://jast.modares.ac.ir/article-23-12125-en.html

Semancik, J.S., A.G. Rakowski, J.A. Bash and D.J. Gumpf. 1997. Application of selected viroids for dwarfing and enhancement of production of 'Valencia' orange. Horticultural Science, 72(4): 563-570.

https://doi.org/10.1080/14620316.1997.11515544

Serra, P., C.J. Barbosa, J.A. Daròs, R. Flores and N. Duran-Vila. 2008. Citrus viroid V: Molecular characterization and synergistic interactions with other members of the genus Apscaviroid. Virology, 370(1): 102-112. https://doi.org/10.1016/j.virol.2007.07.033 
Tangkanchanapas, P., H. Juenak, and K. De Jonghe. 2018. First reported occurrence of citrus bent leaf viroid and citrus dwarfing viroid on imported oranges from China and lime fruits from Cambodia. Journal of Virus Diseases, 29: 416-417.

https://doi.org/10.1007/s13337-018-0466-0

Received: October 30, 2020; Accepted: April 8, 2021
Wu., Q., M. Cao, H. Su, S. Atta, F. Yang, X. Wang and C. Zhou. 2014. Molecular characterization and phylogenetic analysis of Citrus viroid I-LSS variants from citrus in Pakistan and China reveals their possible geographic origin. European Journal of Plant Pathology, 139: 13-17.

https://doi.org/10.1007/s10658-014-0380-2

تاريخ الاستلام: 2020/10/30؛ تاريخ الموافقة على النشر: 2021/4/8 